\title{
THE IMPACT OF NET STABLE FUNDING RATIO ON BANK PERFORMANCE AND RISK AROUND THE WORLD
}

\author{
Bowo Setiyono* and Ahmad Maulin Naufa** \\ *Corresponding author. Assistant Proffesor. Faculty of Economics and Business, Universitas Gadjah Mada, \\ Indonesia. Email: bowo@ugm.ac.id \\ ** Doctoral Student. Faculty of Economics and Business, Universitas Gadjah Mada, Indonesia and \\ Lecturer. BINUS Business School Undergraduate Program, Bina Nusantara University, Indonesia. \\ Email: ahmad.maulin@binus.ac.id
}

\begin{abstract}
This study examines whether liquidity, as measured by net stable funding ratio (NSFR), impacts bank performance and risk. Based on an annual panel data set consisting of 2,909 banks from 127 countries, we find that NSFR reduces both performance and risk. These results are uniquely different in the robustness analysis under various settings (non-linear relationships, high versus low NSFR, and conventional versus Islamic banks). Overall, NSFR implementation brings benefits in the form of risk reduction rather than performance improvement to banks around the world.
\end{abstract}

Keywords: Net stable funding ratio; Liquidity; Risk; Bank; Performance.

JEL Classifications: B26; E52; E58; G21; G28.

Article history:

Received : October 10, 2019

Revised : August 30, 2020

Accepted : September 2, 2020

Available Online: December 31, 2020

https://doi.org/10.21098/bemp.v23i4.1166 


\section{INTRODUCTION}

This research examines the impact of liquidity, measured by $\mathrm{NSFR}^{1}$, on bank performance and risk. This is because, to date, the effect of liquidity on bank performance and risk is still unclear. Prior studies document either a positive or a negative effect of liquidity on bank performance and risk (Ashraf et al., 2016; Grundke \& Kühn, 2019). Besides, understanding the impact of liquidity on bank performance and risk has become more important, given that global financial markets have become extremely volatile, especially under the COVID-19 pandemic. ${ }^{2}$ Managing liquidity is critical to navigating turbulent times (see Phan et al., 2021). Bank liquidity is a crucial issue, since the banks will have a problem when they cannot fulfill depositors' withdrawal or make payment obligations. Frequent liquidity shortages eventually deplete depositors' trust in the ability of the banking system to maintain liquidity, especially during the crisis period (Hong et al., 2014; BCBS, 2018).

A strand of literature documents the inconclusive effect of liquidity on bank performance. In one view, it increases bank performance due to lower cost of capital (King, 2013), higher balance sheet growth (Grundke \& Kühn, 2019), financial stability (Ashraf et al., 2016), and efficiency (Le et al., 2020). In the other view, too much liquid leads to inefficiency (Le et al., 2020), lowers lending rate (Acharya \& Naqvi, 2012), net income (Grundke \& Kühn, 2019), and lending growth (Naceur et al., 2018). Other studies like Dietrich et al. (2014) find no impact of liquidity on bank performance. The impact of liquidity on bank risk is also mixed. Firstly, it reduces risk because it lowers bank failures (Wei et al., 2017), systematic risk (Ly et al., 2017), distress risk (Bologna, 2013), default risk (Grundke \& Kühn, 2019; King, 2013), and liquidity risk (Vazquez \& Federico, 2015). Secondly, higher liquidity is related to higher bank risk due to creating higher bank instability, aggressive lending behavior (Acharya \& Naqvi, 2012), and bank failure (Ghenimi et al., 2017; Wagner, 2007).

Theoretically, Diamond \& Rajan (2001) argue that the fragility of bank deposits (funding liquidity) determines the ability to generate profits from borrowers. If bank funding is stable, the bank will be able to make more profitable investments. The public interest theory states that liquidity enhances profit efficiency, net interest margin, and profits (Barth et al., 2004, Le et al., 2020). Banks with higher NSFR get benefits from better predictability of cash out-and in-flow. On the contrary, Le et al. (2020) find that excessive liquidity could increase inefficiency. This is consistent with the trade-off hypothesis between new liquidity requirements and profitability (King, 2013). Excessive liquidity increases the resilience of banks during stressful

\footnotetext{
1 Banks need to keep their liquidity to mitigate problems like liquidity crunch and bank runs in the future, for which the Basel III requires banks to maintain at least 100\% for both NSFR (Bologna, 2013) and liquidity coverage ratio (LCR) (King, 2013). In this study, we focus on NSFR and we do not estimate LCR because the data required to calculate this ratio is not available. The objective of the LCR is to promote the short-term resilience of the liquidity risk profile of banks (BCBS, 2013).

2 Several studies show that global economies and financial markets have become extremely volatile because of the COVID-19 pandemic (see e.g. Devpura, 2020; Devpura and Narayan, 2020; Iyke, 2020a, b, c; Iyke and Ho, 2020; Narayan, 2020a, b, c; Narayan, Devpura and Wang, 2020; Phan and Narayan, 2020; Sha and Sharma, 2020; Sharma and Sha, 2020; Sharma, 2020). Hence, learning ways to ensure safe and sound banking systems would go a long way to stabilize economies and financial markets.
} 
periods but at the cost of lower profitability. Grundke \& Kühn (2019) find that a higher proportion of high quality and liquid assets leads to decreasing net incomes and bank equity return.

With regards to risk, there are two competing theories. Firstly, the theory of timing liquidity argues that banks with the immediate trading equilibrium tend to adjust their NSFR quickly in response to the Basel III liquidity requirement, thereby reducing systemic risk (Bolton et al., 2011). Consistently, this leads to a lower probability of default and funding risks (Bologna et al., 2013; King, 2013). Secondly, the lending behavior perspective suggests that crises could emerge from flush liquidity, inducing bank managers to behave aggressively by mispricing the downside risk (Acharya \& Naqvi, 2012). When a bank accepts more deposits, it will have a lower funding liquidity risk and shield itself from "run" risk that subsequently reduces market discipline and eventually encourages excessive risktaking (Wagner, 2007).

We hypothesize that liquidity leads to lower bank performance since banks with high liquidity will lose profitable opportunities from loans (Acharya \& Naqvi, 2012). Our second hypothesis is that liquidity reduces risk because it limits over-reliance on short-term yet unstable wholesale funding, hence lowering bank failures, systematic, and liquidity risk (Wei et al., 2017; Ly et al., 2017; Bologna, 2013).

Prior studies are insufficient for the following reasons. Firstly, most of the previous studies have not considered non-linear relationships (Le et al., 2020) between liquidity and performance or risk (Dietrich et al., 2014; Grundke \& Kühn, 2019). Secondly, to best our knowledge, most recent studies ${ }^{3}$ use datasets without considering the post-implementation period of NSFR (Basel III) ${ }^{4}$. Thirdly, previous studies use aggregate country-level data (e.g., King, 2013; Roulet, 2017). Fourthly, previous studies commonly focus on specific banks (i.e. either conventional or Islamic banks), such as Ashraf et al. (2016) for Islamic banks and Naceur et al. (2018) for conventional banks. In this study, we consider both Islamic and conventional banks as additional analysis and compare their results ${ }^{5}$.

Our study provides some benefits especially for policymakers, market participants, and researchers. For policymakers, this study offers new insight into how NSFR should be optimally designed to address liquidity challenges while limiting its adverse impacts. It provides empirical evidence on liquidity impacts on Islamic and conventional banks for bank managers. For market participants, our study encourages the participants to exert more market discipline and monitoring roles. For researchers, this study enhances the NSFR literature by introducing

\footnotetext{
3 Ashraf et al. (2016) consider a sample period of 2000-2013 period, while King (2013) considers only the 2009 period.

4 The NSFR was introduced in October 2014 by BSCB (2014). Yet, its implementation has been in effective in January 2018 and mandatory for all banks in all countries.

5 Islamic banks have different business models that possibly determine the impact of liquidity on performance or risk. They also must comply with regulations issued by both their respective banking authorities and Islamic boards (e.g., Islamic Financial Services Board, IFSB). They determine the adjustments of the assets and liability management, and the nature and behavior of Islamic banks. For example, while the traditional banks put more risk on borrowers, the Islamic bank system adopts risk/profit sharing between the bank and borrowers.
} 
the role of non-linearity in the liquidity-performance/risk relationship and by broadening the context and coverage of bank types.

Our study is distinctive from previous works and offers some new insights. Firstly, we extend previous studies by accommodating non-linear relationships, as earlier discussed (Le et al., 2020; Ly et al., 2017). Secondly, since we do not know the NSFR's ultimate impact yet, our study provides more recent empirical evidence by including the post-implementation period ${ }^{6}$. Thirdly, we employ individual banklevel data to get better inferences, while controlling variabilities across countries or territories. Fourthly, we provide new empirical evidence based on the current mandatory liquidity proxy (NSFR), especially by distinguishing conventional and Islamic banks. Lastly, we offer evidence from 127 countries or territories, allowing us to get more extensive evidence and to control for the different levels of institutional developments across countries.

We uncover the following empirical findings. Firstly, our results indicate that liquidity leads to lower bank performance and risk. The Basel III accord about liquidity (NSFR) helps to reduce risk but it is associated with lower performance. Secondly, we capture the non-linear impact of liquidity on performance and risk. Thirdly, we observe, particularly, that higher liquidity in Islamic banks leads to higher risk in these banks, implying that the liquidity requirements should be adjusted differently for conventional and Islamic banks.

This study contributes to the literature in threefold. Firstly, it improves the empirical evidence on the impact of liquidity on performance and risk in 127 countries by considering a trade-off between performance and risk. Secondly, it emphasizes the identification of the optimum NSFR level, as the Basel committee only regulates its minimum (100\%) because excessive liquidity has an adverse impact on the bank. Thirdly, it shows that conventional and Islamic banks have different characteristics, making their responses to liquidity adjustments different. Hence, the NSFR requirement should be adjusted on the basis of bank type.

The rest of the paper is organized as follows. The next section discusses the data and methodology. Section III provides the results and discussions. Lastly, Section IV draws the conclusions.

\section{DATA AND METHODOLOGY}

A. Data

To examine the impact of NSFR on bank performance and risk, we use data for 2,909 banks from 127 countries over the period 2007 to 2018. Our sample includes both bank-level and country-level data. The bank-level data are sourced from Osiris database, while the county-level data are sourced from the World Development Indicators database published by the World Bank. Osiris database provides information on banks' financial statements, including balance sheets, income statements, and non-financial data, such as ownerships and/or accounting standards. Specifically, we excerpt annual data from banks' balance sheets and income statements to calculate available stable funding (ASF) and required stable

\footnotetext{
6 Among previous studies, Roulet (2017), for instance, focuses on testing the effect of liquidity (NSFR) on bank-lending growth in Europe.
} 


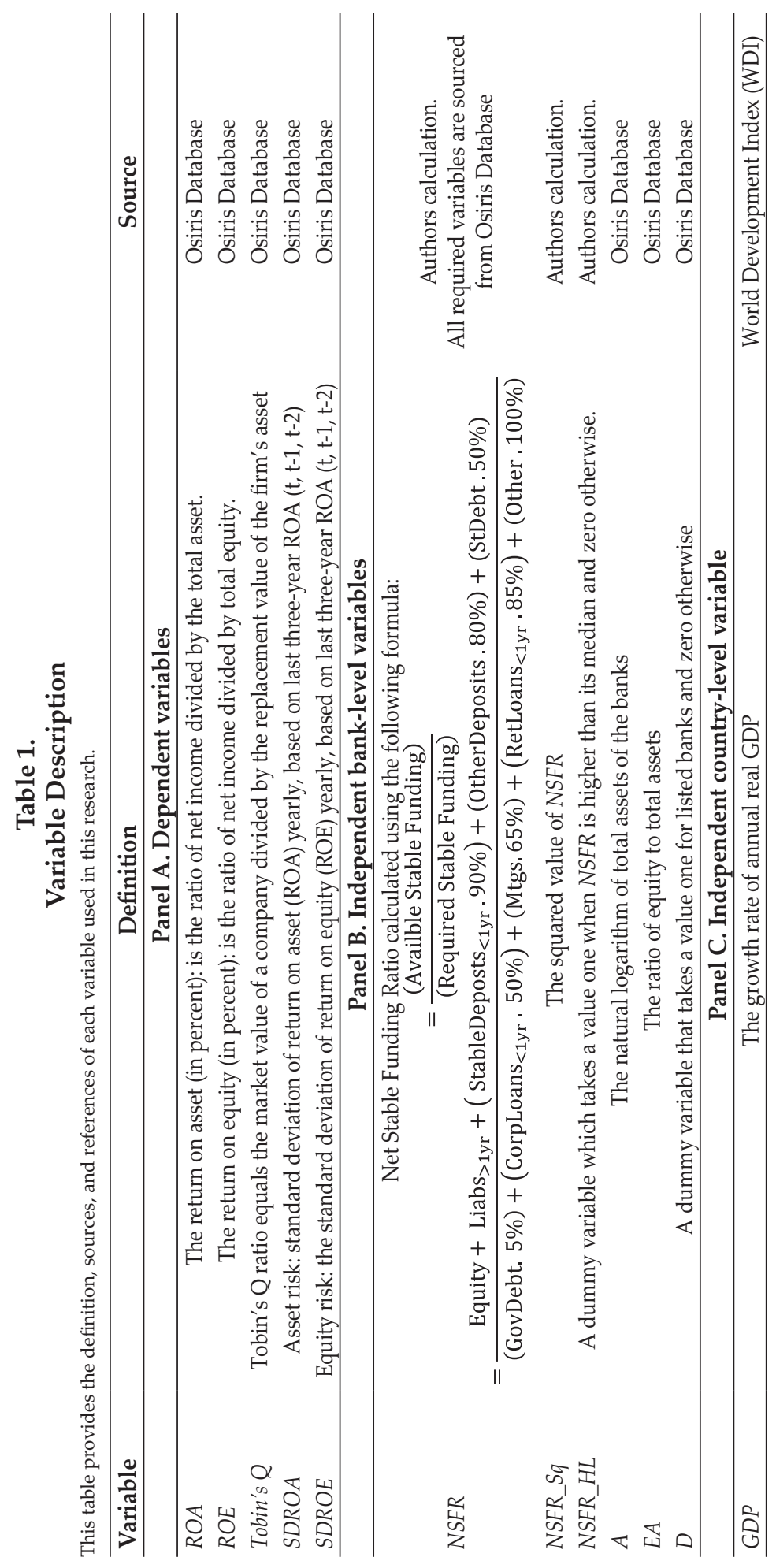


funding (RSF). The ASF and RSF are used to compute the NSFR ratio (see Table 1 and Appendix for detail information). More specifically, to compute the NSFR ratio, we simply follow King's (2013) approach.

We use three proxies of bank performance: (i) Tobin's $Q$, which is the market value of a bank divided by the replacement value of the bank's asset; (ii) return on assets $(R O A)$, which is defined as net income divided by the total assets; and (iii) return on equity $(R O E)$, which is defined as net income divided by the total equity. The choice of the proxies of bank performance is inspired by Bologna (2013) and Dietrich et al. (2014).

Additionally, we compute the standard deviation of return on asset (SDROA) and the standard deviation of return on equity (SDROE) and use these as proxies of bank risk (see Barry et al., 2011; Laeven \& Levine, 2009; Lepetit et al., 2008; Naceur et al., 2018; Dietrich et al., 2014). Moreover, we use two bank-level control variables, namely asset of banks $(A)$, which measures bank size (see also Phan et al., 2021), and the ratio of equity to asset (EA). Finally, we include a country-level control variable, namely the growth rate of gross domestic product (GDP). Our choice of control variables is dictated by prior literature (see Ashraf et al., 2016; Berger \& Bouwman, 2013; Naceur et al., 2018; Khan et al., 2017; Rizvi et al., 2019; Ibrahim \& Law, 2020; and Ly et al., 2017; Phan et al., 2021).

\section{B. Methodology}

We examine the impact of liquidity (NSFR) on bank performance using the following regression model:

$$
B P_{i, t}=\alpha+\beta_{1} N S F R_{i, t}+\beta_{2} A_{i, t}+\beta_{3} E A_{i, t}+\beta_{4} D_{i, t}+\beta_{3} G D P_{j, t}+\varepsilon_{i, t}
$$

where $B P_{i, t}$ denotes performance of bank $i$ and at year $t$. The bank performance is proxied by three variables, namely $R O A, R O E$, and Tobin's $Q$. NSFR $R_{i, t}$ represents bank liquidity; $A_{i, t}$ represents total assets of bank in natural logarithm form; $E A_{i, t}$ denotes equity to the asset ratio; and $D_{i, t}$ represents a dummy variable that takes a value one for listed bank and (zero) otherwise. Listed banks are subject to stricter regulations (i.e., liquidity requirements) and market monitoring that, in turn, will determine their performance (see Liang et al., 2013). Finally, GDP ${ }_{i, t}$ represents annual growth rate of real GDP country (of bank) $j$ at time $i . \varepsilon_{i, t}$ is the residual of the model, while $a$ and $\beta_{i}$ are model parameters.

Additionally, we use two alternative measures for liquidity, namely NSFR_HL and NSFR_Sq. We use NSFR_HL instead of NSFR to distinguish the effect of high or low liquidity (NSFR) on bank performance. Therefore, NSFR_HL represents a dummy variable that takes the value of one if NSFR is higher than its median value and zero otherwise. NSFR_Sq represents squared value of NSFR, which determines the non-linear relationship between NSFR and bank performance. Thus, using these two alternative measures of liquidity (NSFR_HL and NSFR_Sq), we estimate the following two repression models: 


$$
\begin{aligned}
& B P_{i, t}=\alpha+\beta_{1} N S F R_{-} H L_{i, t}+\beta_{2} A_{i, t}+\beta_{3} E A_{i, t}+\beta_{4} D_{i, t}+\beta_{3} G D P_{i, t}+\varepsilon_{i, t} \\
& B P_{i, t}=\alpha+\beta_{1} N S F R_{i, t}+\beta_{2} N S F R_{-} S q_{i, t}+\beta_{2} A_{i, t}+\beta_{3} E A_{i, t}+\beta_{4} D_{i, t}+\beta_{3} G D P_{i, t}+\varepsilon_{i, t}
\end{aligned}
$$

Next, we also examine the effects of NSFR, NSFR_HL and NSFR_Sq on bank risk using the following regression model:

$$
\begin{aligned}
& B R_{i, t}=\alpha+\beta_{1} N S F R_{i, t}+\beta_{2} A_{i, t}+\beta_{3} E A_{i, t}+\beta_{4} D_{i, t}+\beta_{3} G D P_{i, t}+\varepsilon_{i, t} \\
& B R_{i, t}=\alpha+\beta_{1} N S F R_{-} H L_{i, t}+\beta_{2} A_{i, t}+\beta_{3} E A_{i, t}+\beta_{4} D_{i, t}+\beta_{3} G D P_{i, t}+\varepsilon_{i, t} \\
& B R_{i, t}=\alpha+\beta_{1} N S F R_{i, t}+\beta_{2} N S F R_{-} S q_{i, t}+\beta_{2} A_{i, t}+\beta_{3} E A_{i, t}+\beta_{4} D_{i, t}+\beta_{3} G D P_{i, t}+\varepsilon_{i, t}
\end{aligned}
$$

Here, $B R_{i, t}$ denotes the risk of bank $i$ at time $t$. We use two proxies of bank risk, namely SDROA and SDROE. The remaining variables are as defined earlier.

To estimate Equations (1)-(6), we use the generalized method of moments (GMM) estimation technique. ${ }^{7}$ We use the dynamic GMM estimator in order to deal with potential endogeneity problem in our regression model (see Naceur et al., 2018). All bank-level variables are presumably endogenous, and therefore, it is necessary to have one-year lagged value as an instrument variable in the regression framework (see for instance, Dietrich et al., 2014; Ghenimi et al., 2017).

\section{EMPIRICAL RESULTS}

A. Preliminary results

We begin the empirical analysis by discussing selected descriptive statistics reported in Table 2. More specifically, we report the mean, median, minimum, maximum, standard deviation, and the percentile values of all variables used in this study. The mean value of NSFR is 0.82 , which is very close to unity indicating that, on average, most of the banks achieved the minimum requirement (1.00) set by the Basel committee. With respect to the NSFR_HL statistics, we note that approximately $30 \%$ of the banks maintain high liquidity positions. The mean values of SDROA and SDROE are $1.39 \%$ and $7.82 \%$, respectively. We also note that the SD of SDROE (26.28) is greater than the SD of SDROA (6.78).

\footnotetext{
We have also used ordinary least squares (OLS) and fixed-effects estimators to conduct our empirical analysis. However, due to space constraint, we do not report these results in the paper. These results are available upon request from the corresponding author.
} 


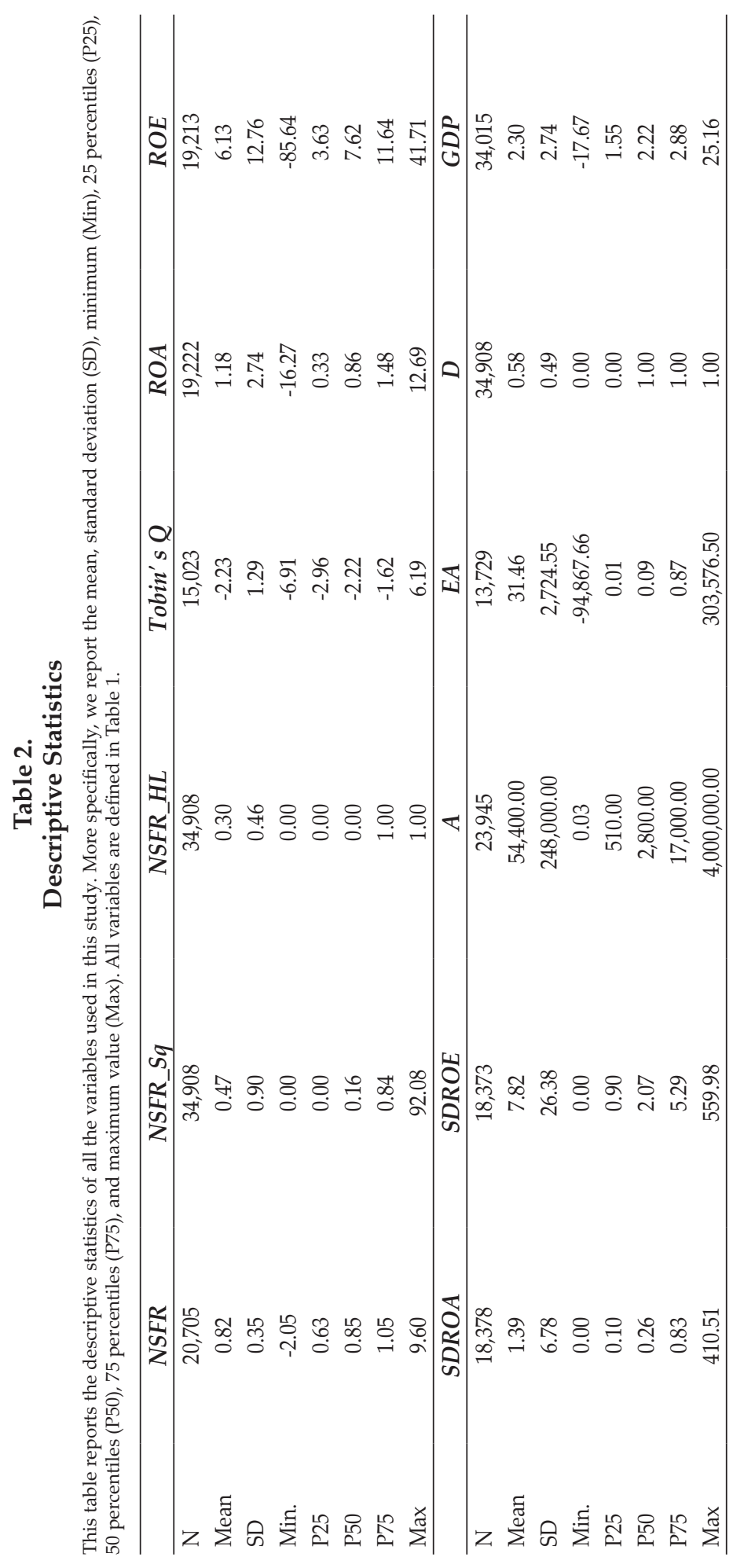




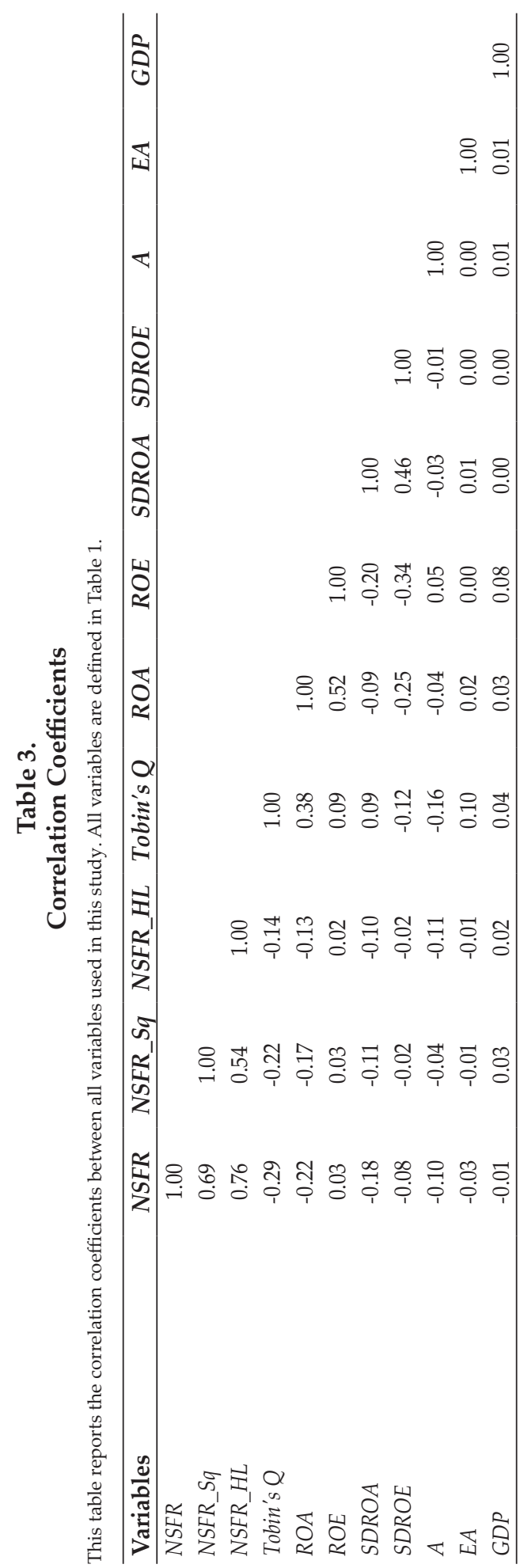


Next, we report the correlation coefficients between all variables considered in this study in Table 2 . We note that NSFR is negatively correlated with two proxies of bank performance, namely Tobin's $Q$ and $R O A$, and is positively correlated with $R O E$. With respect to bank risk variables, we find that NSFR is negatively correlated with SDROA and SDROE.

\section{B. Main findings}

The results based on the relationship between liquidity and bank performance are reported in Table 4. More specifically, the results based on the three liquidity proxies, namely NSFR, NSFR_HL and NSFR_Sq are reported in Panels A-C, respectively. We find that NSFR has a negative and statistically significant effect on two measures of bank performance, namely Tobin's $Q$ and $R O A$. Our findings remain same when we use NSFR_HL and NSFR_Sq in the regression model. Additionally, we report that, irrespective of the liquidity measure used, the results related to $R O E$ remain statistically insignificant. In other words, we do not find any significant evidence related to the relationship between NSFR and ROE.

Our findings with respect to Equation (3), which include both NSFR and NSFR_Sq as explanatory variables, is that the coefficient of NSFR_Sq is statically significant and positive, but the sign of the NSFR coefficient is negative. This means that the impact of liquidity on bank performance becomes weaker (less negative) once we consider non-linearity. Our results are consistent with Le et al. (2020), who document that the relationship between liquidity and bank performance is nonlinear. In other words, our findings suggest that excessive liquidity has a minimal negative impact on bank performance.

Overall, our findings are consistent with prior studies, which document that an increase in liquidity leads to lower bank performance (see for instance, Le et al., 2020; Acharya \& Naqvi, 2012; Grundke \& Kühn, 2019; Naceur et al., 2018); in other words, this implies that more liquid banks are associated with lower profitability. 


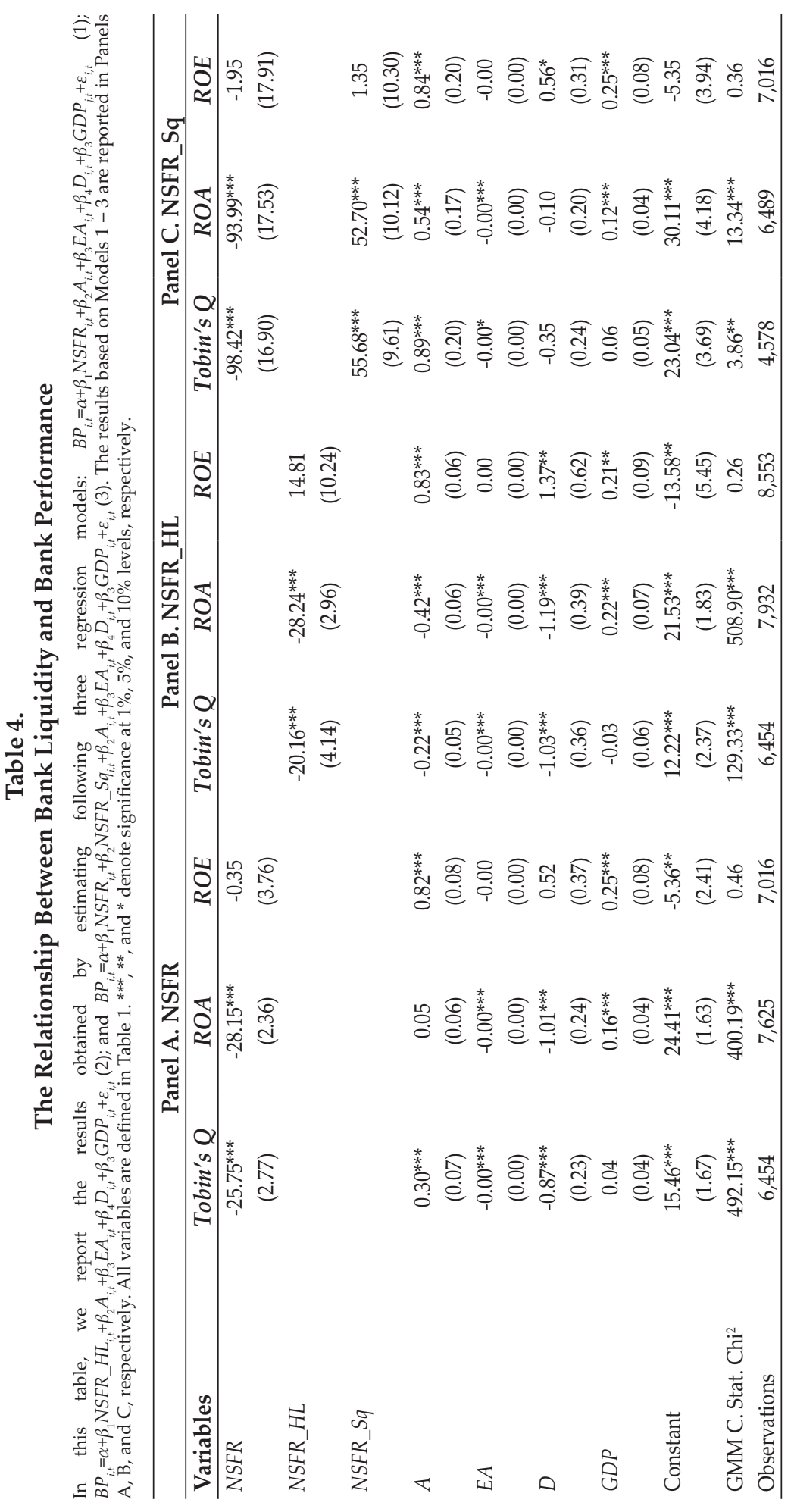


When banks maintain their liquidity (NSFR), they reduce loans from unstable funds, thereby lowering lending, and, consequently, lowering profit. Higher liquidity decreases the lending rate (Acharya \& Naqvi, 2012), lending growth (Naceur et al., 2018), and bank inefficiency (Le et al., 2020). We conclude that our findings are consistent with the trade-off hypothesis, which states that too much liquidity may have a detrimental effect on bank performance (see King, 2013).

Next, we read the results in Table 5. Here, we report the results obtained by estimating Equations (4) - (6), which examines the impact of bank liquidity on bank risk proxied by two variables, namely SDROA and SDROE. Our results based on the three measures of bank liquidity, namely NSFR, NSFR ${ }_{L H^{\prime}}$ and NSFR_S $q$ are reported in Panels A, B, and C, respectively. Our findings suggest that the NSFR has a negative and statistically significant effect on bank risk. These findings are consistent with all three models as well as with the use of two risk variables (SDROA and SDROE). Our results support Wei et al. (2017), Ly et al. (2017), Bologna (2013), King (2013), and Vazquez and Federico (2015). Thus, we conclude that higher liquidity helps in reducing bank risk. Our findings are, once again, consistent with prior studies (see for example, King, 2013). Additionally, our findings are consistent with the argument that the higher the reliance on the less-stable components, the more likely a bank is to face distress (see for example Bologna, 2013; Grundke \& Kühn, 2019).

Table 5.

The Relationship Between Bank Liquidity and Bank Risk

In this table, we report the results obtained by estimating the following three regression models: $B R_{i, t}=\alpha+\beta_{1} N S F R_{i, t}+\beta_{2} A_{i, t}+\beta_{3} E A_{i, t}+\beta_{4} D_{i, t}+\beta_{3} G D P_{i, t}+\varepsilon_{i, t} \quad(4) ; \quad B R_{i, t}=\alpha+\beta_{1} N S F R_{-} H L_{i, t}+\beta_{2} A_{i, t}+\beta_{3} E A_{i, t}+\beta_{4} D_{i, t}+\beta_{3} G D P_{i, t}+\varepsilon_{i, t} \quad$ (5); and $B R_{i, t}=\alpha+\beta_{1} N S F R_{i, t}+\beta_{2} N S F R \_S q_{i, t}+\beta_{2} A_{i, t}+\beta_{3} E A_{i, t}+\beta_{4} D_{i, t}+\beta_{3} G D P_{i, t}+\varepsilon_{i, t}(6)$. Results based on Models $4-6$ are reported in Panels $\mathrm{A}, \mathrm{B}$, and $\mathrm{C}$, respectively. All variables are defined in Table 1 . ${ }^{* * *},{ }^{* *}$, and ${ }^{*}$ denote significance at $1 \%, 5 \%$, and $10 \%$ levels, respectively.

\begin{tabular}{lcccccc}
\hline & \multicolumn{2}{c}{ Panel A. NSFR } & \multicolumn{2}{c}{ Panel B. NSFR_HL } & \multicolumn{2}{c}{ Panel C. NSFR_Sq } \\
\hline Variables & SDROA & SDROE & SDROA & SDROE & SDROA & SDROE \\
\hline NSFR & $-32.27^{* * *}$ & $-33.20^{* * *}$ & & & $-57.14^{* * *}$ & $-78.85^{* * *}$ \\
& $(6.63)$ & $(8.94)$ & & & $(15.76)$ & $(28.15)$ \\
NSFR_HL & & & $-43.98^{* * *}$ & $-29.52^{* * *}$ & & \\
NSFR_Sq & & & $(9.05)$ & $(8.25)$ & & \\
& & & & & $31.02^{* * *}$ & $45.11^{* * *}$ \\
A & & & & & $(8.97)$ & $(16.16)$ \\
& $0.21^{*}$ & $0.51^{* * *}$ & $-0.34^{* * *}$ & -0.09 & $0.44^{* *}$ & 0.20 \\
EA & $(0.12)$ & $(0.17)$ & $(0.10)$ & $(0.08)$ & $(0.18)$ & $(0.37)$ \\
& $-0.00^{* * *}$ & $-0.00^{* * *}$ & $-0.00^{* * *}$ & $-0.00^{* * *}$ & $-0.00^{* *}$ & -0.00 \\
D & $(0.00)$ & $(0.00)$ & $(0.00)$ & $(0.00)$ & $(0.00)$ & $(0.00)$ \\
& $-1.17^{* * *}$ & $-1.13^{* * *}$ & $-1.91^{* * *}$ & $-1.46^{* *}$ & 0.10 & $-1.22^{*}$ \\
GDP & $(0.35)$ & $(0.42)$ & $(0.69)$ & $(0.60)$ & $(0.16)$ & $(0.73)$ \\
& $0.15^{* *}$ & $0.14^{* *}$ & $0.27^{* *}$ & 0.14 & $0.07^{*}$ & -0.03 \\
Constant & $(0.07)$ & $(0.07)$ & $(0.13)$ & $(0.10)$ & $(0.04)$ & $(0.16)$ \\
& $24.99^{* * *}$ & $21.01^{* * *}$ & $27.65^{* * *}$ & $16.87^{* * *}$ & $17.02^{* * *}$ & $32.85^{* * *}$ \\
GMM C. Stat. Chi ${ }^{2}$ & $(4.05)$ & $(5.31)$ & $(4.65)$ & $(4.28)$ & $(3.45)$ & $(5.95)$ \\
Observations & $3.60^{*}$ & $193.56^{* * *}$ & $3.90^{* *}$ & $424.36^{* * *}$ & $4.39^{* *}$ & 1.27 \\
\hline
\end{tabular}




\section{Additional results}

Given our data sample contains both conventional and Islamic banks, it is wise to conduct the analysis by dividing these banks into groups. Therefore, in this section, we re-estimate all six equations by dividing banks into a panel of 66 Islamic and 2,843 conventional banks. This grouping is important because Islamic and conventional banks operates very differently and there is a literature, which explores a wide range of issues with respect to these two different groups of banks (see for instance, Narayan et al., 2018; Ibrahim \& Law, 2020; Juhro et al., 2020). We begin by examining the impact of bank liquidity on Islamic and conventional banks' performance and report the results in Table 6. Our estimation approach is the same as explained earlier.

Our findings are twofold. Firstly, we document that our findings related to conventional banks remain same as the baseline. More specifically, we document that the NSFR has a negative and statistically significant effect on Tobin's $Q$ and $R O A$ of the conventional banks, irrespective of model used, but we do not find any statistically significant evidence in the case of ROA. For the Islamic banks, however, we find weak evidence with respect to the relationship between liquidity and bank performance. We document that the NSFR has a negative and statistically significant effect on only one proxy of Islamic bank performance, namely Tobin's $Q$, but $R O A$ and $R O E$. 


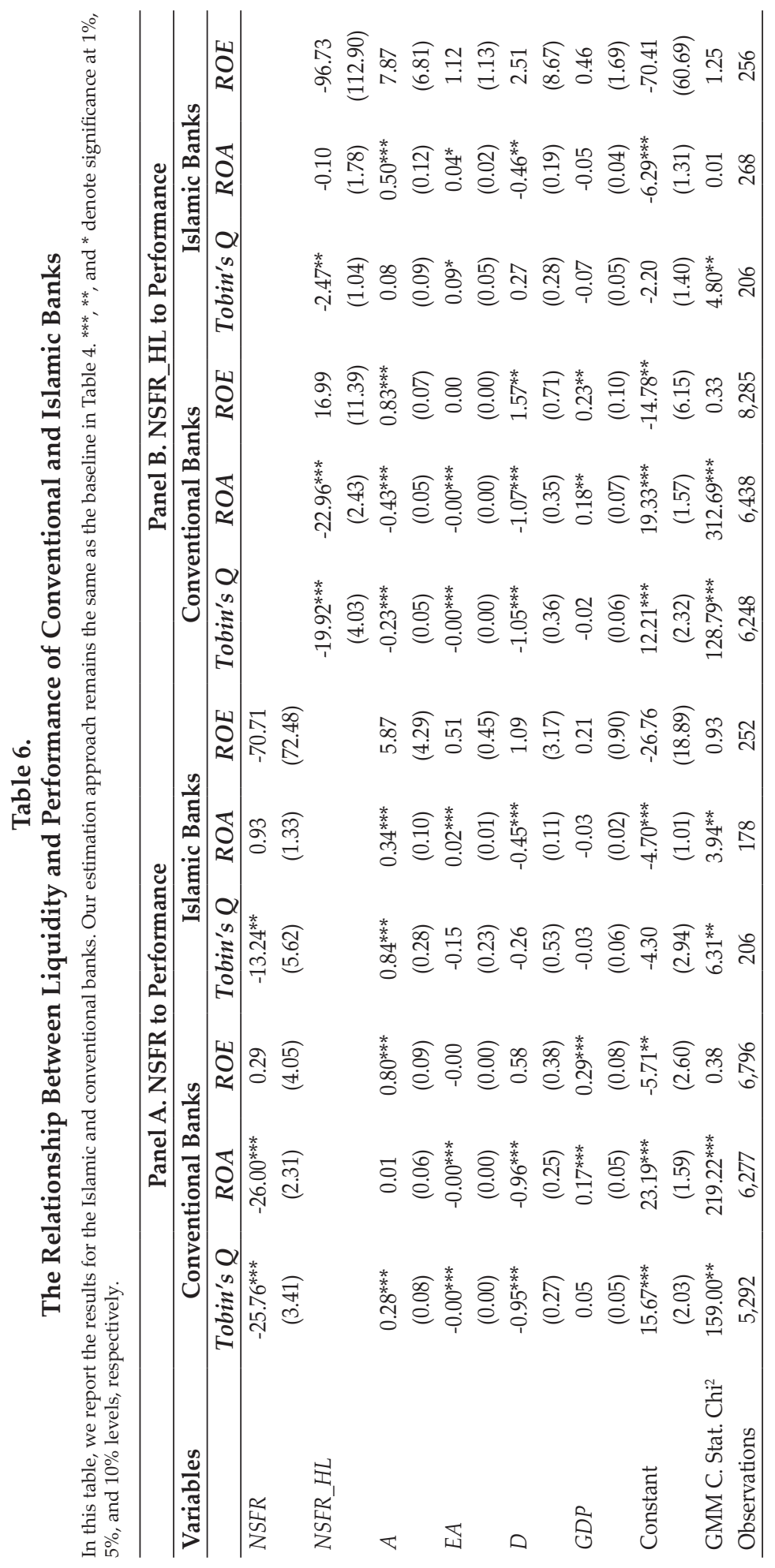




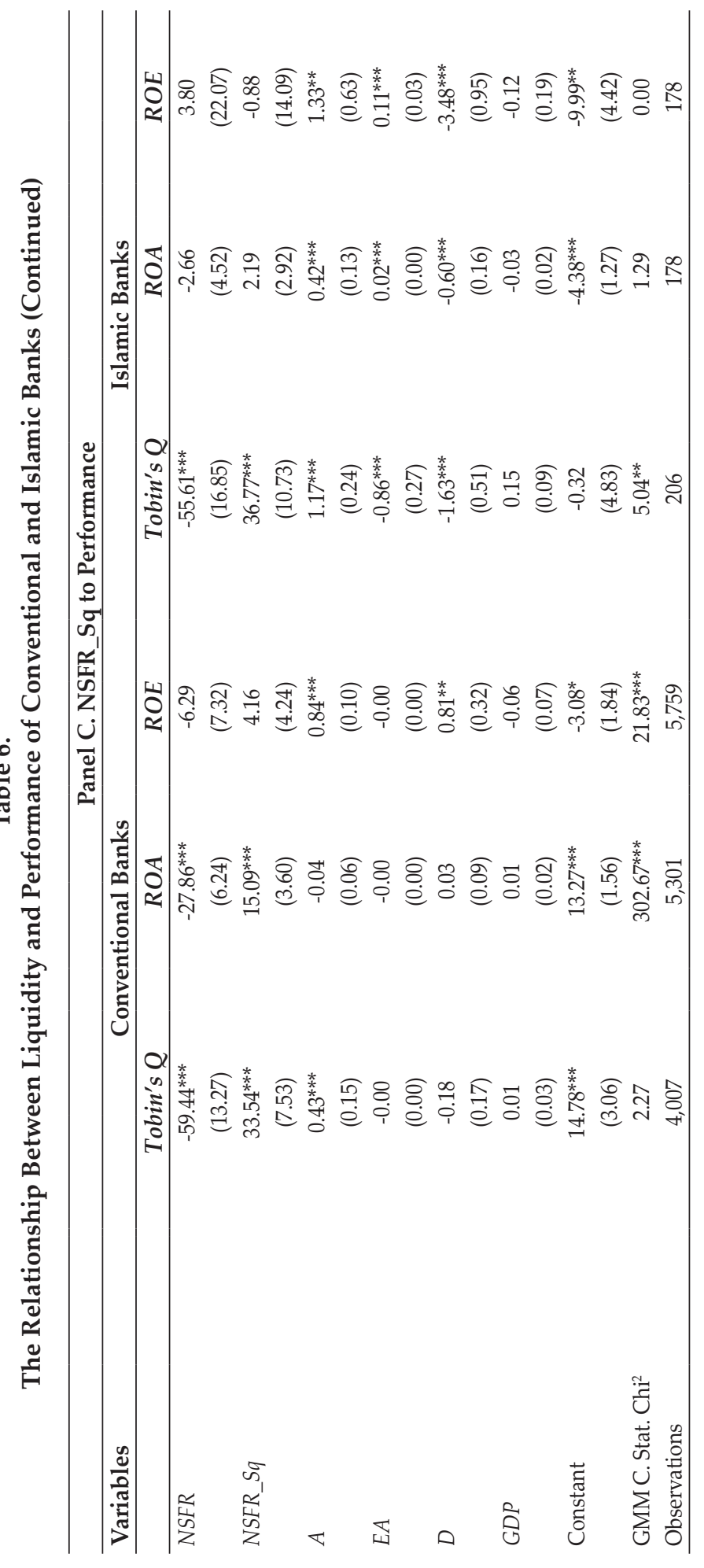




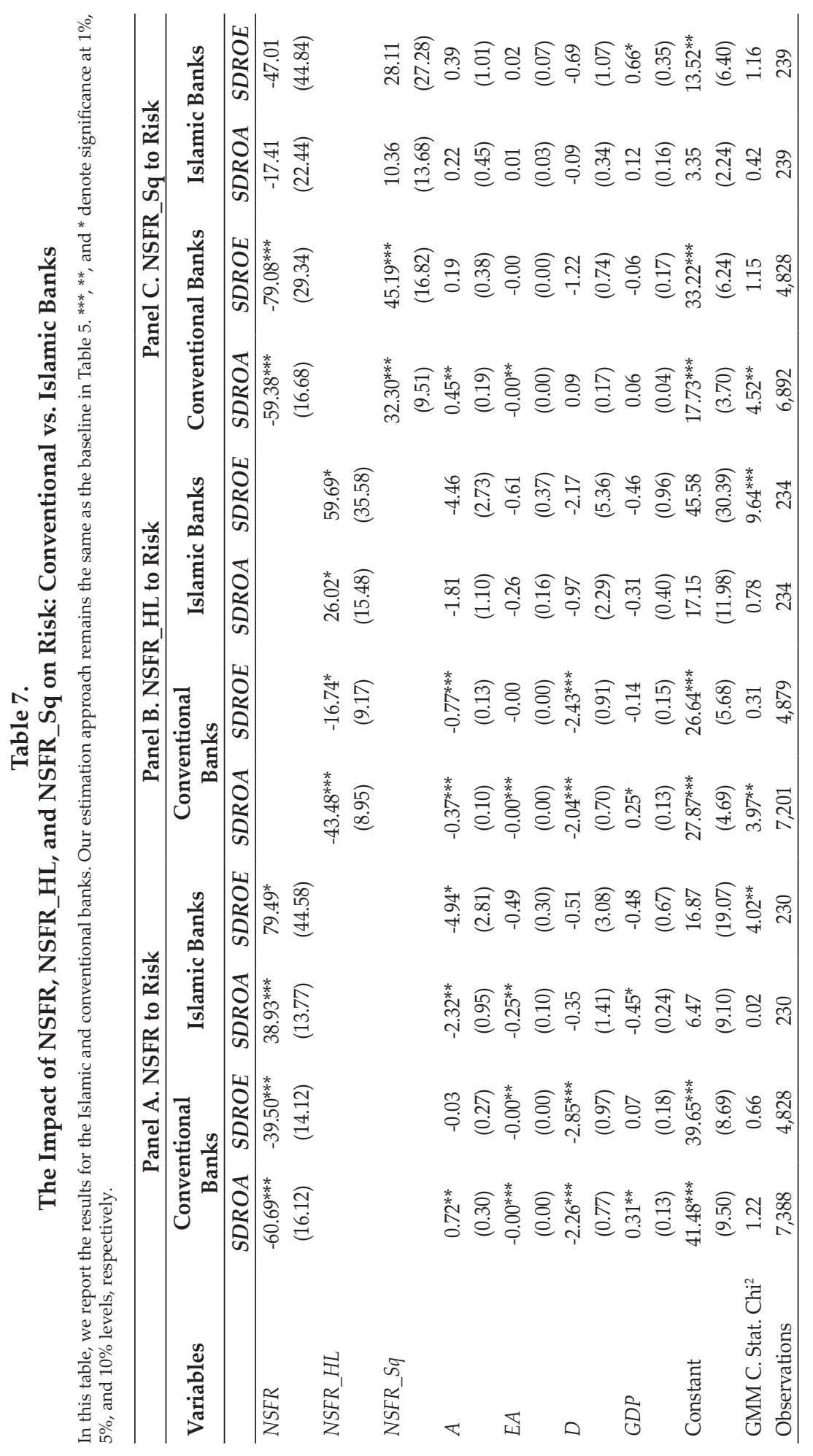


Finally, we examine the impact of bank liquidity on Islamic and conventional bank risk and report in Table 7. Our findings with respect to conventional banks is same as the baseline (i.e. the estimates using all 2,909 banks). More specifically, we report that the NSFR has a negative and statistically significant effect conventional bank risk. However, we cannot say same about Islamic banks. Our findings with respect to Islamic banks is mixed. For instance, in regression models where we use NSFR (refer to Equation 4) and NSFR_HL (refer to Equation 5) as proxies for bank liquidity, we find that bank liquidity has a positive and statistically significant effect on Islamic bank risk. This evidence is consistent with Ashraf et al. (2016), who document that, while seeking higher profits, Islamic banks engage in high risk-taking behavior. The asset and liability of Islamic banks are structured to be more equity-based contracts and they are more eager to take a high risk to pursue higher profitability. There is a risk-return trade-off experienced by Islamic banks. Ashraf et al. (2016) further documents that Islamic banks are more unstable than their counterparts. Islamic banks are subject to stricter regulations compared to conventional banks. Hence, our findings highlight the notion that Islamic banks face different circumstances, including how they manage liquidity as well as its ultimate impact on their performance and risk.

\section{CONCLUSION}

This study investigates the impact of liquidity on bank performance and bank risk. We use data for 2,909 banks from 127 countries. We draw the following conclusions from our empirical analysis. Firstly, we document that bank liquidity has a negative effect on bank performance and as well as on bank risk. Secondly, we unveil that the effect of bank liquidity varies across Islamic and conventional banks. Our findings with respect to conventional banks remain unchanged; we document a negative relationship between bank liquidity and bank performance and bank risk. However, in the case of Islamic banks, we document a weak evidence in favour of the relationship between bank liquidity and Islamic banks performance and bank risk. Finally, we conclude that our findings are mostly consistent using different proxies of bank performance and bank risk.

\section{REFERENCES}

Acharya, V., \& Naqvi, H. (2012). The seeds of a crisis: A theory of bank liquidity and risk taking over the business cycle. Journal of Financial Economics, 106, 349366. https://doi.org/10.1016/j.jfineco.2012.05.014

Ashraf, D., Rizwan, M. S., \& L'Huillier, B. (2016). A net stable funding ratio for Islamic banks and its impact on financial stability: An international investigation. Journal of Financial Stability, 25, 47-57. https://doi.org/10.1016/j. jfs.2016.06.010

Barry, T. A., Lepetit, L., \& Tarazi, A. (2011). Ownership structure and risk in publicly held and privately owned banks. Journal of Banking and Finance, 35, 1327-1340. https://doi.org/10.1016/j.jbankfin.2010.10.004

Barth, J. R., Jr, C. G., \& Levine, R. (2004). Bank regulation and supervision: what works best? Journal of Financial Intermedation, 13, 205-248. https://doi. org/10.1016/j.jfi.2003.06.002 
Basel Committee on Banking Supervision (BCBS). (2013). Basel III: The liquidity coverage ratio and liquidity risk monitoring tools. Bank for International Settlements. https://www.bis.org/publ/bcbs238.htm

Basel Committee on Banking Supervision (BCBS). (2018). Basel Committee on Banking Supervision: Fifteenth progress report on adoption of the Basel regulatory framework. Bank for International Settlements. https://www.bis.org/bcbs/publ/ d452.htm

Berger, A. N., \& Bouwman, C. H. S. (2013). How does capital affect bank performance during financial crises? Journal of Financial Economics, 1-31. https://doi.org/10.1016/j.jfineco.2013.02.008

Bologna, P. (2013). Structural Funding and Bank Failures: Does Basel 3 Net Stable Funding Ratio Target the Right Problem? Journal of Financial Services Research, 47, 81-113. https://doi.org/10.1007/s10693-013-0180-4

Bolton, P., Santos, T., \& Scheinkman, J. A. (2011). Outside and inside liquidity. Quarterly Journal of Economics, 126, 259-321. https://doi.org/10.1093/qje/qjq007

Devpura, N. (2020). Can Oil Prices Predict Japanese Yen? Asian Economics Letters, 1. https://doi.org/10.46557/001c.17964

Devpura, N., \& Narayan, P.K., (2020) Hourly Oil Price Volatility: The Role of COVID-19. Energy Research Letters, 1, 13683. https://doi.org/10.46557/001c.13683

Diamond, D. W., \& Rajan, R. G. (2001). Liquidity Risk, Liquidity Creation, and Financial Fragility: A Theory of Banking. Journal of Political Economy, 109, 287327. https://doi.org/10.1086/319552

Dietrich, A., Hess, K., \& Wanzenried, G. (2014). The Good and Bad News about the New Liquidity Rules of Basel III in Western European countries. Journal of Banking and Finance, 44, 13-25. https://doi.org/10.1016/j.jbankfin.2014.03.041

Ghenimi, A., Chaibi, H., \& Omri, M. A. B. (2017). The effects of liquidity risk and credit risk on bank stability: Evidence from the MENA region. Borsa Istanbul Review, 17, 238-248. https://doi.org/10.1016/j.bir.2017.05.002

Grundke, P., \& Kühn, A. (2019). The impact of the Basel III liquidity ratios on banks: Evidence from a simulation study. Quarterly Review of Economics and Finance. https://doi.org/10.1016/j.qref.2019.02.005

Hong, H., Huang, J. Z., \& Wu, D. (2014). The information content of Basel III liquidity risk measures. Journal of Financial Stability, 15, 91-111. https://doi. org/10.1016/j.jfs.2014.09.003

Ibrahim, M. H., \& Law, S. H. (2020). Financial intermediation costs in a dual banking system: The role of islamic banking. Buletin Ekonomi Moneter Dan Perbankan, 22, 529-550. https://doi.org/10.21098/bemp.v22i4.1236

Iyke, B. (2020a). COVID-19: The Reaction of US Oil and Gas Producers to the Pandemic. Energy Research Letters, 1, 13912. https://doi.org/10.46557/001c.13912

Iyke, B.N. (2020b). The Disease Outbreak Channel of Exchange Rate Return Predictability: Evidence from COVID-19. Emerging Markets Finance and Trade, 56, 2277-2297. https://doi.org/10.1080/1540496X.2020.1784718.

Iyke, B. N. (2020c). Economic Policy Uncertainty in Times of COVID-19 Pandemic. Asian Economics Letters, 1. https://doi.org/10.46557/001c.17665

Iyke, B. N. \& Ho, S.-Y. (2020). Investor attention on COVID-19 and African stock returns. MethodsX. https://doi.org/10.1016/j.mex.2020.101195 
Juhro, S. M., Narayan, P. K., Iyke, B. N., \& Trisnanto, B. (2020). Is there a role for Islamic finance and R\&D in endogenous growth models in the case of Indonesia?. Pacific-Basin Finance Journal, 62, 101297. https://doi.org/10.1016/j. pacfin.2020.101297

Khan, S. M., Scheule, H., \& Wu, E. (2017). Funding liquidity and bank risk taking. Journal of Banking and Finance, 82, 203-216. https://doi.org/10.1016/j. jbankfin.2016.09.005

King, M. R. (2013). The Basel III Net Stable Funding Ratio and bank net interest margins. Journal of Banking and Finance, 37, 4144-4156. https://doi.org/10.1016/j. jbankfin.2013.07.017

Laeven, L., \& Levine, R. (2009). Bank governance, regulation and risk taking. Journal of Financial Economics, 93, 259-275. https://doi.org/10.1016/j.jfineco.2008.09.003

Le, M., Hoang, V. N., Wilson, C., \& Managi, S. (2020). Net stable funding ratio and profit efficiency of commercial banks in the US. Economic Analysis and Policy, 67, 55-66. https://doi.org/10.1016/j.eap.2020.05.008

Lepetit, L., Nys, E., Rous, P., \& Tarazi, A. (2008). Bank income structure and risk : An empirical analysis of European banks. Journal of Banking and Finance, 32, 1452-1467. https://doi.org/10.1016/j.jbankfin.2007.12.002

Liang, Q., Xu, P., \& Jiraporn, P. (2013). Board characteristics and Chinese bank performance. Journal of Banking and Finance, 37, 2953-2968. https://doi. org/10.1016/j.jbankfin.2013.04.018

Ly, K. C., Chen, Z., Wang, S., \& Jiang, Y. (2017). The Basel III net stable funding ratio adjustment speed and systemic risk. Research in International Business and Finance, 39, 169-182. https://doi.org/10.1016/j.ribaf.2016.07.031

Naceur, B. S., Marton, K., \& Roulet, C. (2018). Basel III and bank-lending: Evidence from the United States and Europe. Journal of Financial Stability, 39, 1-27. https://doi.org/10.1016/j.jfs.2018.08.002

Narayan, P. K. (2020a). Oil price news and COVID-19-Is there any connection?. Energy Research Letters, 1, 13176. https://doi.org/10.46557/001c.13176

Narayan, P. K. (2020b). Has COVID-19 Changed Exchange Rate Resistance to Shocks? Asian Economics Letters, 1. https://doi.org/10.46557/001c.17389

Narayan, P. K. (2020c). Did Bubble Activity Intensify During COVID-19? Asian Economics Letters, 1. https://doi.org/10.46557/001c.17654

Narayan, P.K., Devpura, N., \& Wang, H. (2020). Japanese currency and stock market-What happened during the COVID-19 pandemic? Economic Analysis and Policy, 68, 191-198.

Narayan, P.K., Sharma, P.K., Thuraisamy, K.S., \& Westerlund, J. (2018). Some Preliminary Evidence of Price Discovery in Islamic Banks. Pacific-Basin Finance Journal, 52, 107-122. https://doi.org/10.1016/j.pacfin.2017.12.007

Phan, D. H. B., Iyke, B. N., Sharma, S. S., \& Affandi, Y. (2021). Economic policy uncertainty and financial stability-Is there a relation?. Economic Modelling, 94, 1018-1029. https://doi.org/10.1016/j.econmod.2020.02.042

Phan, D.H.B., \& Narayan, P.K. (2020). Country responses and the reaction of the stock market to COVID-19 - a Preliminary Exposition. Emerging Markets Finance and Trade, 56, 2138-2150. https://doi.org/10.1080/1540496X.2020.1784719 
Rizvi, S. A. R., Narayan, P. K., Sakti, A., \& Syarifuddin, F. (2019). Role of Islamic banks in Indonesian banking industry: an empirical exploration. Pacific Basin Finance Journal, 62, 1-10. https://doi.org/10.1016/j.pacfin.2019.02.002

Roulet, C. (2017). Basel III: Effects of Capital and Liquidity regulations on European Bank Lending. Journal of Economics and Business. https://doi.org/10.1016/j. jeconbus.2017.10.001

Sha, Y., \& Sharma, S. S. (2020). Research on pandemics special issue of the journal Emerging Markets Finance and Trade (2020): 2133-2137.

Sharma, S.S., \& Sha, Y. (2020) Part A: Special Section on COVID-19 Research. Emerging Markets Finance and Trade, 56, 3551-3553. https://doi.org/10.1080/154 0496X.2020.1858617

Sharma, S. S. (2020). A Note on the Asian Market Volatility During the COVID-19 Pandemic. Asian Economics Letters, 1. https://doi.org/10.46557/001c.17661

Vazquez, F., \& Federico, P. (2015). Bank funding structures and risk: Evidence from the global financial crisis. Journal of Banking and Finance, 61, 1-14. https:// doi.org/10.1016/j.jbankfin.2015.08.023

Wagner, W. (2007). The liquidity of bank assets and banking stability. Journal of Banking and Finance, 31, 121-139. https://doi.org/10.1016/j.jbankfin.2005.07.019

Wei, X., Gong, Y., \& Wu, H. M. (2017). The impacts of Net Stable Funding Ratio requirement on Banks' choices of debt maturity. Journal of Banking and Finance, 82, 229-243. https://doi.org/10.1016/j.jbankfin.2017.02.006 


\section{Appendix A. Net Stable Funding Ratio and Its Components}

The table shows net stable funding ratio and its components. The table is adapted from King (2013).

\begin{tabular}{|c|c|}
\hline Required Stable Funding (RSF) & RSF Weight \\
\hline \multicolumn{2}{|l|}{ Gross loans } \\
\hline \multicolumn{2}{|l|}{ Net loans } \\
\hline Residential mortgage loans & 0.85 \\
\hline Other mortgage loans & 0.85 \\
\hline Other consumer/retail loans & 0.85 \\
\hline Corporate \& Commercial loans & 0.85 \\
\hline Other loans & 0.85 \\
\hline Memo: Mandatory reserves included above & 1.00 \\
\hline Loans and advances to banks & 0.00 \\
\hline \multicolumn{2}{|l|}{ Total securities } \\
\hline \multicolumn{2}{|l|}{ Reserves repos and cash collateral } \\
\hline \multicolumn{2}{|l|}{ Plus: trading securities and at FV through income } \\
\hline \multicolumn{2}{|l|}{ Plus: derivatives } \\
\hline \multicolumn{2}{|l|}{ Plus: available for sale securities } \\
\hline \multicolumn{2}{|l|}{ Plus: Held to maturity securities } \\
\hline \multicolumn{2}{|l|}{ Plus: other securities } \\
\hline Memo government securities included above (level 1) & 0.05 \\
\hline Total securities (level 2) & 0.50 \\
\hline At-equity investment in associates & 1.00 \\
\hline Other earning assets & 1.00 \\
\hline Cash and due from banks & 0.00 \\
\hline Total assets (non-interest earning asset) & 1.00 \\
\hline \multicolumn{2}{|l|}{ Less: total earning asset } \\
\hline Off-balance sheet & 0.05 \\
\hline Available Stable Funding (ASF) & ASF Weight \\
\hline \multicolumn{2}{|l|}{ Customer deposits } \\
\hline Customer deposits-current & 0.90 \\
\hline Customer deposits-savings & 0.95 \\
\hline Customer deposits-term & 0.95 \\
\hline Deposits from banks & 0.00 \\
\hline \multicolumn{2}{|l|}{ Wholesale short-term borrowing } \\
\hline One month -6 months & 0.00 \\
\hline Six months -12 months & 0.50 \\
\hline Long-term borrowing & 1.00 \\
\hline Derivatives liabilities & 0.00 \\
\hline Trading liabilities & 0.00 \\
\hline Other liabilities (tax, pension, insurance) & 0.00 \\
\hline Equity & 1.00 \\
\hline
\end{tabular}


This page is intentionally left blank 